\title{
Recurrent partial mortality events in winter shape the dynamics of the zooxanthellate coral Oculina patagonica at high latitude in the Mediterranean
}

\author{
Eduard Serrano ${ }^{1}$, Marta Ribes ${ }^{2}$, Rafel Coma ${ }^{1}$ \\ ${ }^{1}$ Centre d'Estudis Avançats de Blanes-Consejo Superior de Investigaciones Científicas (CEAB- \\ CSIC), Blanes, Spain \\ ${ }^{2}$ Institut de Ciències del Mar-Consejo Superior de Investigaciones Científicas (ICM-CSIC), \\ Barcelona, Spain
}

Published in: Coral Reefs (2016)

DOI: $10.1007 / \mathrm{s} 00338-016-1510-4$ 


\begin{abstract}
Global warming has many biological effects on corals and plays a central role in the regression of tropical coral reefs; therefore, there is an urgent need to understand how some coral species have adapted to environmental conditions at higher latitudes. We examined the effects of temperature and light on the growth of the zooxanthellate coral Oculina patagonica (Scleractinia, Oculinidae) at the northern limit of its distribution in the eastern Iberian Peninsula (western Mediterranean) by transplanting colonies onto plates and excluding them from space competition over a $\sim 4$-yr period. Each year, most of the colonies ( $70 \%$ ) exhibited denuded skeletons with isolated polyps persisting on approximately half of the coral surface area. These recurrent episodes of partial coral mortality occurred in winter, and their severity appeared to be related to colony exposure to cold but not to light. Although O. patagonica exhibited high resistance to stress, coral linear extension did not resume until the coenosarc regenerated. The resumption of linear extension was related to the dissociation of the polyps from the coenosarc and the outstanding regenerative capacity of this species $\left(10.3 \mathrm{~mm}^{2} \mathrm{~d}^{-1}\right)$. These biological characteristics allow the species to survive at high latitudes. However, the recurrent and severe pattern of denuded skeletons greatly affects the dynamics of the species and may constrain population growth at high latitudes in the Mediterranean.
\end{abstract}

Keywords: Zooxanthellate coral, Partial mortality, Lesion regeneration, Linear extension dynamics, Cold thermal stress, Mediterranean Sea 


\section{INTRODUCTION}

Latitudinal variation in environmental parameters determines coral biogeography. Temperature, solar radiation, nutrients and the saturation state of seawater aragonite are critical factors for photosynthesis and the calcification of zooxanthellate corals, and these variables co-vary with increasing latitude, thus limiting coral growth at high latitudes [e.g., Kleypas et al. 1999; Muir et al. 2015]. The scarcity of zooxanthellate corals in temperate areas is related to the effects of environmental parameters, competition with macroalgae and the synergistic interactions of biotic and abiotic factors [e.g., Miller 1998; Hoegh-Guldberg 1999]. However, the current decline of coral reefs in both perturbed and unperturbed areas indicates that increasing temperature is a global stressor that is playing a crucial role in the regression of reef ecosystems [e.g., Hughes et al. 2010]. Temperature has long been considered to be the primary factor controlling the distribution of coral species [e.g., HoeghGuldberg 1999; Kleypas et al. 1999], and exposure to both high and low stressful temperatures has been documented to reduce coral growth and cause bleaching and mortality [e.g., Saxby et al. 2003; Hoegh-Guldberg et al. 2005; Colella et al. 2012; Roth et al. 2012].

Global warming is affecting many biological aspects of coral species; even the more conservative warming projections indicate that many tropical reefs may enter a noncoraldominant stage before the end of the century [Hoegh-Guldberg and Bruno 2010; Pandolfi et al. 2011; Frieler et al. 2013]. Corals are among the organisms least expected to exhibit poleward movement because their capacity to adapt is usually outpaced by the current, rapid rate of environmental change due to human activities [Hoegh-Guldberg 2012]. However, the distribution of some zooxanthellate scleractinian corals has shifted to higher latitudes in some areas, tracking the movement of suitable temperatures [e.g., Takao et al. 2015], and marginal habitats for coral reefs are predicted to expand in future climate scenarios [Freeman 2015]. Understanding the ability of such coral species to adapt to environmental changes at high latitudes is crucial to predict shifts in coral communities in response to climate change. 
In the shallow rocky assemblages of the temperate Mediterranean Sea, both local evidence of phase shifts from macroalgal to coral dominance and the rapid expansion of Oculina patagonica (Scleractinia, Oculinidae) [Serrano et al. 2012, 2013; Salomidi et al. 2013; Rodolfo-Metalpa et al. 2014] provide evidence that this zooxanthellate coral may be displaying invasive behavior that could challenge the current conceptual framework of the ecosystem [Miller 1998]. Such behavior is consistent with the fact that O. patagonica, first documented in the Mediterranean in 1966, is currently found in many areas throughout the Mediterranean Sea [Rubio-Portillo et al. 2014a and references therein]. A recent study indicated that the species is not a recent introduction, and thus its current taxonomic status is unclear because it cannot be reliably classified as either "native" or "introduced" [Leydet and Hellberg 2015]. The most abundant O. patagonica populations have been recorded along the coast of the eastern Iberian Peninsula [Balearic Sea; Fine et al. 2001; Coma et al. 2011; Serrano et al. 2012, 2013; Rubio-Portillo et al. 2014a]. However, although this coral has been expanding northward from the north Balearic Sea $\left(40^{\circ} \mathrm{N}\right)$ toward the Gulf of Lyon $\left(42^{\circ} \mathrm{N}\right)$ over the last two decades [Serrano et al. 2013], little is known about its growth dynamics in the expansion zone.

Similar to tropical corals, the growth rate of $O$. patagonica in the western Mediterranean is positively correlated with a certain temperature range [Rodolfo-Metalpa et al. 2008]. Prolonged exposure to sublethal warm-temperature thresholds has been reported to damage O. patagonica colonies in short-term field studies ( $<2 \mathrm{yr})$ and surveys [Rodolfo-Metalpa et al. 2008, 2014; Rubio-Portillo et al. 2014b], and long-term studies in the eastern Mediterranean have shown that the species suffers severe annual bleaching and mortality events in summer [Fine et al. 2001; Shenkar et al. 2005] that are mainly related to exposure to high temperature [Ainsworth et al. 2008]. In this study, we addressed the effect of temperature and light on $O$. patagonica growth dynamics in the expansion zone at the northern limit of its population distribution along the Iberian Peninsula [Serrano et al. 2013], a critical first step toward understanding the response of this species to climate change. We assessed the seasonal variation in growth and mortality of $O$. patagonica colonies over a $\sim 4$ yr period. Although long-term monitoring studies are labor intensive, they are fundamental to acquiring a thorough understanding of the factors that influence the life cycles of long- 
lived species such as corals, and they enable predictions of how such species might be affected by climate change. The effects of these abiotic factors were examined by transplanting coral colonies onto plates and excluding them from space competition with other organisms. The results of this study provide new insights into the seasonal and annual growth dynamics of $O$. patagonica at the northern limit of its distribution and contribute to an understanding of the biological characteristics that allow some zooxanthellate corals to thrive in temperate systems.

\section{MATERIALS AND METHODS}

\section{Sample collection}

In August 2008, the encrusting colonial coral O. patagonica was sampled at L'Ampolla breakwater $\left(40^{\circ} 49^{\prime} \mathrm{N}, 0^{\circ} 43^{\prime} \mathrm{E}\right)$ in the north Balearic Sea (northwest Mediterranean Sea; Fig. 1) by scuba diving at depths of $2-5 \mathrm{~m}$. Coral fragments $(\sim 3 \mathrm{~cm}$ in diameter) were collected with a hammer and chisel from widely separated $(>3 \mathrm{~m})$ and healthy $(<10 \%$ colony partial mortality) colonies $(\mathrm{n}=29)$ that ranged between 25 and $40 \mathrm{~cm}$ in maximum diameter. The coral specimens were immediately placed in large seawater containers and transported to the Experimental Aquarium Zone at the Institute of Marine Sciences in Barcelona $(<4 \mathrm{~h})$. Shortly after, the coral samples were carefully cleaned of epiphytes and sediment, and each was glued onto a methacrylate plate $(15 \times 15 \mathrm{~cm})$ with an inert mastic compound. The coral plates were placed in a $225-\mathrm{L}$ acclimation tank equipped with a circulation pump and running natural seawater. The inlet and outlet pipes remained open so that the acclimation tank functioned as a flow-through open system, and the corals were maintained in aquaria under controlled conditions until the perimeter of the entire colony was growing onto the plastic plates. During the $\sim 3$-month acclimation period in the aquaria, the natural seawater temperature (ST) was gradually decreased from 25 to $18^{\circ} \mathrm{C}$, and the light conditions were adjusted to $150 \mu \mathrm{mol}$ photons $\mathrm{m}^{-2} \mathrm{~s}^{-1}$ (12:12 light:dark photoperiod) to simulate late summer/early autumn conditions at the study area (Fig. 2). 


\section{Study site and experimental design}

In November 2008, the 29 coral plates were transported back and randomly fixed onto a rocky reef located $\sim 5 \mathrm{~km}$ north of the collection site (Fig. 1). The thermal and light regimes did not differ between the collection and experimental sites (Electronic Supplementary Material, ESM, Supplementary methods). Therefore, we will generally refer to the study area as L'Ampolla. In the study area, O. patagonica has a patchy distribution on shallow rocky reefs with locally abundant populations [Serrano et al. 2013]. All coral plates were installed on slightly inclined surfaces $\left(<45^{\circ}\right)$ at depths of $4-5 \mathrm{~m}$ within a $\sim 400-\mathrm{m}^{2}$ rocky area oriented parallel to the shore $(80 \times 5 \mathrm{~m})$. The coral plates were monitored over a $\sim 4$-yr period (November 2008-August 2012, $\mathrm{n}=17$ sampling dates) at an average sampling interval of $87 \pm 8 \mathrm{~d}(\mathrm{SE}, \mathrm{n}=16)$. The benthic community surrounding the plates was dominated by algal communities with a canopy height $>2 \mathrm{~cm}$. On each sampling date, the coral plates were cleaned of settling organisms (commonly turf algae $<1 \mathrm{~cm}$ in height) to ensure that the corals were not exposed to algal competition, and any algae that settled on the coral skeleton were removed during the surveys.

\section{Colony partial mortality and growth}

On each sampling date, all coral plates were photographed in situ using a ruler as a size reference. Because colonies of $O$. patagonica have an encrusting morphology, the colony surface area from a planar view and the area experiencing partial mortality were measured from photographs using ImageJ software. Colony partial mortality was evaluated for each sampling date as the percentage of the colony area showing signs of mortality (i.e., denuded skeleton or coverage by sessile organisms). Partial mortality was further classified into three levels of severity: mild $(<15 \%)$, moderate $(15-85 \%)$ or severe $(>85 \%)$. At the beginning of the study (November 2008), mean partial mortality was $2 \pm 1 \%(\mathrm{SE}, \mathrm{n}=29)$. Colony partial mortality rates between sampling dates were calculated by dividing the change in partial mortality from one sampling date to the next by the number of days in the sampling interval expressed as a percentage of the colony area $\left(\% \mathrm{~d}^{-1}\right)$ and as $\mathrm{mm}^{2} \mathrm{~d}^{-1}$. The rate of variation in planar area between sampling dates was calculated by dividing the accumulated colony 
surface area from one sampling date to the next by the number of days in the sampling interval $\left(\mathrm{cm}^{2} \mathrm{~d}^{-1}\right)$. The change in arithmetic mean diameter appears to be the most appropriate method to standardize linear growth rate data of coral colonies versus the initial size, particularly for encrusting species that tend to grow primarily in the horizontal plane and have circular areas [Pratchett et al. 2015], such as O. patagonica (Fig. 3). Then, to provide a size-independent measure of the linear extension rate $\left(\mathrm{cm}\right.$ diameter $\left.\mathrm{d}^{-1}\right)$, the planar area $\left(\mathrm{A}, \mathrm{cm}^{2}\right)$ was translated to the arithmetic mean diameter $(\mathrm{D}, \mathrm{cm})$ using the formula $D=$ $2 * \sqrt{A / \pi}$. The mean annual linear extension rate was estimated for each study year by integrating the mean daily values of the different sampling intervals.

\section{Environmental data}

Global solar radiation $\left(\mathrm{J} \mathrm{m}^{-2}\right)$ throughout the study period was recorded by the Ebre Observatory (located $50 \mathrm{~m}$ above sea level; Fig. 1). The daily photosynthetically active radiation (PAR, mol photons $\mathrm{m}^{-2} \mathrm{~d}^{-1}$ ) at a depth of $5 \mathrm{~m}$ was obtained from global irradiance and light attenuation coefficient data (ESM Supplementary methods). The mean annual and monthly PAR were determined based on the daily values averaged over the study period.

ST was recorded hourly throughout the study period using onset HOBO pendant temperature data loggers (UA-002-64) placed at a depth of $5 \mathrm{~m}$, and the mean annual and monthly STs were determined based on the averaged daily values. We also calculated the number of days in which the mean daily ST was above and below different thresholds $(\geq 20$ to $\geq 28^{\circ} \mathrm{C}$ and $\leq 19$ to $\leq 11^{\circ} \mathrm{C}$, respectively).

\section{Statistical analysis}

The individual and combined relationships between coral performance (partial mortality and linear extension rates) and environmental parameters (PAR and ST) were assessed by multiple regression using the mean PAR and ST calculated for each sampling interval. Cross-correlation analyses were used to establish relationships between the environmental 
parameters (PAR and ST) over time and to determine the relationship between $O$. patagonica performance and ST. One-way repeated-measures ANOVA was used to test the inter-annual differences in mean partial mortality and linear extension rates, combined with Tukey's test for post hoc comparison. A Chi-squared $\left(\chi^{2}\right)$ test was used to examine the interannual variability in ST thresholds. We used STATISTICA version 7.0 for the analyses, and the results are expressed as the mean $\pm \mathrm{SE}$.

\section{RESULTS}

\section{Environmental parameters}

The mean annual PAR at L'Ampolla (5 m depth) during the study period was $19.5 \pm 0.7$ mol photons $\mathrm{m}^{-2} \mathrm{~d}^{-1}(2009-2011, \mathrm{n}=3)$ and ranged between 18.3 and $20.8 \mathrm{~mol}$ photons $\mathrm{m}^{-2}$ $\mathrm{d}^{-1}$ (Fig. 2a). The light regime was characterized by marked seasonality, with monthly mean PARs ranging from $6.1 \mathrm{~mol}$ photons $\mathrm{m}^{-2} \mathrm{~d}^{-1}$ in December 2009 to $36.6 \mathrm{~mol}$ photons $\mathrm{m}^{-2} \mathrm{~d}^{-1}$ in July 2010 (Fig. 2a; daily mean PAR values are shown in ESM Fig. S1a). Two periods were distinguished based on the monthly mean PARs: (1) a high-radiation period from April to September $\left(27.3 \pm 1.0 \mathrm{~mol}\right.$ photons $\left.\mathrm{m}^{-2} \mathrm{~d}^{-1}, \mathrm{n}=3\right)$ and $(2)$ a low-radiation period from October to March (12.1 \pm 0.6 mol photons $\mathrm{m}^{-2} \mathrm{~d}^{-1}, \mathrm{n}=3$; Fig. 2a).

The mean annual ST at L'Ampolla was $18.5 \pm 0.4^{\circ} \mathrm{C}(2009-2011, \mathrm{n}=3)$ and ranged between 17.7 and $18.9^{\circ} \mathrm{C}$ (Fig. 2b). The thermal regime was characterized by marked seasonality with monthly mean STs ranging from $11.7^{\circ} \mathrm{C}$ in February 2010 to $27.1^{\circ} \mathrm{C}$ in August 2009 and a mean thermal amplitude of $13.9 \pm 0.2^{\circ} \mathrm{C}$ during the annual cycle. The minimum mean daily ST was observed in February $2010\left(10.1^{\circ} \mathrm{C}\right)$, and the maximum occurred in August 2009 (28.6 ${ }^{\circ}$; ESM Fig. S1b). Based on the monthly mean STs, two periods were identified (each separated by a 1-month shift): (1) a cold period from December to April $\left(13.5 \pm 0.1^{\circ} \mathrm{C}, \mathrm{n}=4\right)$ with a warming shift in May $\left(18.1 \pm 0.4^{\circ} \mathrm{C}, \mathrm{n}=4\right)$ and (2) a warm period from June to October $\left(23.6 \pm 0.5^{\circ} \mathrm{C}, \mathrm{n}=3\right)$ with a cooling shift in November $\left(17.4 \pm 0.6^{\circ} \mathrm{C}, \mathrm{n}=4\right.$; Fig. $\left.2 \mathrm{~b}\right)$. 
The PAR and thermal regimes exhibited similar seasonal trends but with a time delay (i.e., the maximum seasonal peaks in ST shifted to the right relative to the maximum peaks in PAR; Fig. 2). Based on the daily means, cross-correlation analysis revealed that the highest positive Pearson correlation coefficients were between the ST and the PAR measured 1-2 months earlier (the maximum correlation at $-40-\mathrm{d}$ lag, $r=0.79$; ESM Fig. S1c). The wavelike form of the cross-correlation plot, with peaks separated by $\sim 6$ months, reflected the seasonal nature of the changes in PAR and ST.

\section{Annual cycle of coral partial mortality}

The seasonal advent of partial mortality (i.e., tissue loss resulting in a denuded skeleton) and recovery in the $O$. patagonica colonies was the most predominant process and occurred each year throughout the four annual cycles examined at L'Ampolla (Fig. 3). The phenomenon of partial mortality began affecting small, unconnected parts of the coenosarc, exposing the denuded coenosteum in different (central and peripheral) but isolated parts of the colony (i.e., multifocal distribution; e.g., January in Fig. 3). In this first phase, partial mortality usually followed a progressive coalescence of the multifocal denuded skeleton that was conducive to the loss of nearly the entire coenosarc, but the remaining polyps remained healthy (alive and brown in color) and isolated within the calyx (e.g., April in Fig. 3). The phenomenon was rarely observed in the final phase, in which the isolated polyps disappeared from parts of the colony, leaving a completely denuded skeleton.

The first symptoms of denuded partial mortality were detected in December, and the symptoms increased until April of each year when the highest values were detected (49 \pm 9\%, 2009-2012, n = 4; Fig. 4a). The April peak in partial mortality resulted in the highest percentage of colonies with moderate and severe partial mortality $(>15 \%, 75 \pm 10 \%$; ESM Fig. S2). The mean rate of partial mortality from December to April was $0.32 \pm 0.08 \% \mathrm{~d}^{-1}$ (n $=7$; Fig. $4 \mathrm{~b}, \mathrm{c}$ ), which is equivalent to $10.0 \pm 3.1 \mathrm{~mm}^{2} \mathrm{~d}^{-1}$. The colonies started to exhibit signs of recovery in May, when the tissue surrounding the denuded skeleton began to recover. The mean annual peak in the tissue regeneration rate from May to July was $-0.35 \pm$ $0.02 \% \mathrm{~d}^{-1}\left(2009-2012, \mathrm{n}=4\right.$; Fig. $4 \mathrm{~b}$, c), which is equivalent to $-10.3 \pm 2.7 \mathrm{~mm}^{2} \mathrm{~d}^{-1}$. By 
July, the mean extent of partial mortality was reduced to $24 \pm 4 \%$ of the April peak each year (2009-2012, n = 4; Fig. 4a). Some overgrowth of the denuded coral skeleton by filamentous and foliose algae and deposition of sediment particles occurred during the mortality and recovery periods (Fig. 3), so after this rapid recovery phase, tissue regeneration of the remaining areas of partial mortality continued at a slower pace from August to November $\left(-0.05 \pm 0.03 \% \mathrm{~d}^{-1}, \mathrm{n}=5\right.$; Fig. $\left.4 \mathrm{~b}, \mathrm{c}\right)$. Partial mortality rate values from this slow recovery phase were excluded in the regression analysis with environmental parameters, because lesion regeneration was already completed or affected by algae overgrowth. Overall, the regeneration process led to the lowest mean extent of partial mortality $(4-8 \%, 2009-2011, \mathrm{n}=3)$ and the lowest percentage of colonies with mild partial mortality $(<15 \%, 96 \pm 2 \%)$ in November; these values remained low until the initiation of the subsequent partial mortality event in December (Fig. 4a; ESM Fig. S2). The occurrence of a recently denuded skeleton and/or visually apparent bleaching was not observed from May to November in any of the study years (Figs. 3, 4).

\section{Annual cycle of coral growth}

The mean size of the O. patagonica colonies increased from $10 \pm 1 \mathrm{~cm}^{2}$ in November 2008 to $60 \pm 12 \mathrm{~cm}^{2}$ in August 2012 at a mean linear extension rate of $13.27 \pm 2.95 \mathrm{~cm}^{2} \mathrm{yr}^{-1}$ (Fig. 5a), which is equivalent to a mean increase in colony diameter of $1.27 \pm 0.19 \mathrm{~cm} \mathrm{yr}^{-1}$. The maximum linear extension rate of an individual colony was $2.47 \mathrm{~cm}$ diameter $\mathrm{yr}^{-1}$. Coral growth exhibited a marked pattern of seasonal variation that repeatedly occurred during the $\sim 4$-yr study period (Fig. 5). The mean linear extension rate reached a minimum during the 6 months from December to May $\left(0.0016 \pm 0.0007 \mathrm{~cm}\right.$ diameter $\mathrm{d}^{-1}, \mathrm{n}=9$; Fig. $5 \mathrm{~b}, \mathrm{c}$ ), which coincided with a decrease in living colony size (i.e., the extent of the coral tissue, which is complementary to the proportion of partial mortality) between December and April (Fig. 5a). Despite this decline in live tissue, coral skeleton growth resumed in June following the rapid tissue regeneration that started in May (Fig. 5a). The mean linear extension rate during the $\sim 6$ months from June to November (growing period) was $0.0058 \pm$ $0.0007 \mathrm{~cm}$ diameter $\mathrm{d}^{-1}(\mathrm{n}=7$; Fig. $5 \mathrm{~b}, \mathrm{c})$. 


\section{Coral mortality and growth in relation to environmental variables}

The rate of O. patagonica partial mortality was negatively related to ST $(\mathrm{p}=0.0290)$ but did not exhibit a significant relationship with PAR $(\mathrm{p}=0.64)$ (multiple regression: $\mathrm{F}_{2,8}=$ $15.79, \mathrm{r}^{2}=0.80, \mathrm{p}=0.0017, \mathrm{n}=11$; values from the slow recovery phase were excluded). The proportion of colony partial mortality and ST displayed opposite trends but with a time delay (i.e., the maximum seasonal peaks in partial mortality shifted right relative to the minimum peaks in ST; Fig. 4a), and cross-correlation analysis indicated that ST and the proportion of partial mortality were negatively correlated and that the highest Pearson correlation coefficient was associated with a lag of $-78 d(r=-0.68$; ESM Fig. S3a). These results indicated that the pattern of increased partial mortality was preceded by the minimum ST values 2-3 months earlier (i.e., the April peak in partial mortality was related to the lowest ST in January-February; Fig. 4a). The rate of partial mortality and ST exhibited opposite trends with no time delay (i.e., the maximum seasonal peaks in partial mortality rate coincided with the minimum peaks in ST; Fig. 4b; ESM Fig. S3b), and there was a negative relationship between the two variables $\left(\mathrm{r}^{2}=0.79, \mathrm{p}=0.0002, \mathrm{n}=11\right)$, indicating that the positive mortality rate values might be related to the $<14^{\circ} \mathrm{C}$ threshold that commonly occurred from December to April (Fig. 6a). These results suggest that cold STs are an important factor influencing $O$. patagonica partial mortality in the study area.

The linear extension rate of $O$. patagonica colonies was positively related to ST $(\mathrm{p}=$ $0.0008)$ but did not have a significant relationship with PAR $(\mathrm{p}=0.10)$ (multiple regression: $\left.\mathrm{F}_{2,13}=12.63, \mathrm{r}^{2}=0.66, \mathrm{p}=0.0009\right)$. The linear extension rate and ST exhibited similar trends with no time delay (i.e., the maximum peaks in the linear extension rate coincided with the maximum peaks in ST; Fig. 5b, ESM Fig. S3c), and there was a positive relationship between the two variables, with higher linear extension rates related to the $>16^{\circ} \mathrm{C}$ threshold that commonly occurred from May to November (Fig. 6b). These results suggest that warm STs are an important factor increasing O. patagonica linear extension in the study area.

These results demonstrate that ST is related to both partial mortality and linear extension of the species. Consequently, a cross-correlation analysis was conducted to examine the 
potential trade-offs between the two processes. The highest negative correlation between colony partial mortality and linear extension rates occurred at a -48-d lag (ESM Fig. S3d), indicating that the high partial mortality rate from the previous 1-2 months negatively affected linear extension of the colonies.

\section{Inter-annual variability in coral mortality and growth in relation to ST}

The yearly peak in mean denuded partial mortality observed in April was always associated with similarly low values of partial mortality due to overgrowth in November (28\%, 2008-2011), despite the fact that the April peak in 2009 (26\%) was approximately half as large as those in 2010, 2011 and 2012 (48, 57 and 66\%, respectively; Fig. 4a). Similarly, the percentage of colonies suffering from moderate to severe partial mortality $(>15 \%)$ in April 2009 (45\%) was 45-51\% lower than those in 2010, 2011 and 2012 (83, 82 and 91\%, respectively; ESM Fig. S2). The annual peak in the partial mortality rate was also lower in $2009\left(0.18 \pm 0.04 \% \mathrm{~d}^{-1}\right)$ than in 2010, 2011 and $2012\left(0.54 \pm 0.03 \% \mathrm{~d}^{-1}\right.$; one-way repeatedmeasures ANOVA, $\left.\mathrm{F}_{3,84}=10.62, \mathrm{p}<0.0001\right)$. The number of days that $\mathrm{ST}$ was $\leq 19$ to $\leq 13^{\circ} \mathrm{C}$ did not vary significantly among the cold periods studied (2008-2009 to 2011-2012, $\left.\mathrm{n}=4 ; \chi^{2}, \mathrm{p}>0.05\right)$. However, the mean number of days that ST was $\leq 12^{\circ} \mathrm{C}$ was $20 \pm 4 \mathrm{~d}$ in 2009-2010, 2010-2011 and 2011-2012, a threshold that was not reached during the cold period of 2008-2009 $\left(\chi^{2}, \mathrm{p}<0.05\right.$; ESM Table S1). These results indicate that the occurrence of partial mortality was lower during the less severe cold period of 2008-2009 than during the other three more severe cold periods.

Generally, colony partial mortality occurred during the cold period (December-April) and was followed by tissue regeneration and linear extension. The annual peak in the regeneration rate was similar among the studied years $\left(0.35 \pm 0.02 \% \mathrm{~d}^{-1}, 2009-2012\right.$; oneway repeated-measures ANOVA, $\mathrm{F}_{3,84}=0.84, \mathrm{p}>0.05$ ). Hence, the time required for nearly complete regeneration of the tissue (i.e., when the lowest partial mortality values, of $4-8 \%$, were first reached) appeared to be related to the severity of the annual partial mortality episodes (i.e., the time required for regeneration was longer in years showing high denuded partial mortality in April), which contributed to the interannual variation of the duration of 
the negative effect of partial mortality on the linear extension rate. As a result, the lower incidence of partial mortality in 2009 resulted in complete regeneration by June, but as the incidence of partial mortality increased in the following years (2010 and 2011), the regeneration time was longer (September and December, respectively; Fig. 4). This pattern is consistent with the higher linear extension rate observed in May $2009(0.0063 \pm 0.0008$

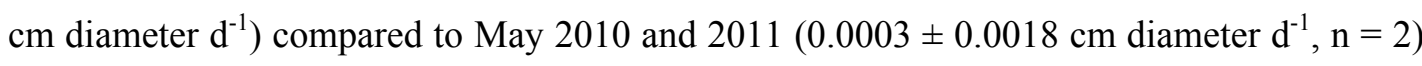
and the twofold higher peak in the linear extension rate in July-August in 2009 (0.0100 \pm

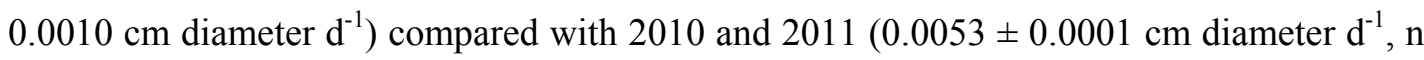
$=2$; Fig. $5 \mathrm{~b}, \mathrm{c}$ ). The mean annual linear extension rate of $O$. patagonica was twofold higher in $2009\left(1.91 \pm 0.25 \mathrm{~cm}\right.$ diameter $\left.\mathrm{yr}^{-1}\right)$ than in 2010 and $2011(0.86 \pm 0.22$ and $1.03 \pm 0.27$

$\mathrm{cm}$ diameter $\mathrm{yr}^{-1}$, respectively; one-way repeated-measures ANOVA, $\mathrm{F}_{2,56}=19.36, \mathrm{p}<$ 0.0001). These results indicate that ST may be exerting a direct effect on the growth dynamics of the species as well as an indirect effect through partial mortality. The number of days in which the ST was $\geq 20$ to $\geq 24^{\circ} \mathrm{C}$ did not vary significantly among the warm periods during the study (2009-2011, $\mathrm{n}=3 ; \chi^{2}, \mathrm{p}>0.05$ ), whereas the $\geq 25$ to $\geq 27^{\circ} \mathrm{C}$ thresholds in the 2009 warm period were higher than those in 2010 and $2011\left(\chi^{2}, \mathrm{p}<0.05\right.$; ESM Table S1). For instance, the number of days in which the ST was $\geq 25^{\circ} \mathrm{C}$ was 25 and $60 \%$ higher in 2009 than in 2010 and 2011, respectively. However, recently denuded skeletons and/or visually apparent bleaching were not observed during the summer and fall in any of the study years.

\section{DISCUSSION}

\section{Pattern of partial mortality and tissue regeneration}

The yearly occurrence of denuded partial mortality in the O. patagonica colonies in winter (December-April) was the most distinctive process observed during the study. The denuded skeleton resulted from progressive tissue loss, which caused a loss of coloniality (i.e., dissociation of polyps from their connective coenosarc). The presence of colonies with 
brown, isolated polyps within the calyx distributed over a white coenosteum was a sign of the observed partial mortality, which we usually refer to as a Dalmatian mortality pattern (Fig. 7). The usual persistence of isolated brown polyps on the colonies distinguished the observed pattern of mortality from the pattern of tissue loss documented at the end of summer in colonies from Albissola, Monaco and Portman; although these colonies also exhibit areas of isolated brown polyps, they commonly display patches of completely denuded skeleton (i.e., the coenosteum and calyx; Rodolfo-Metalpa et al. 2008, 2014) that were rarely observed in our study. The process of denuded partial mortality that affected the colonies at our study site during winter resembled that observed in February 2006 in Monaco [Rodolfo-Metalpa et al. 2008]. Colonies responded a similar way to reduced $\mathrm{pH}$ conditions in aquaria [Kvitt et al. 2015]. The process observed in February 2006 did not appear to impact the dynamics of the species because the colonies completely regenerated by May, and the process was only observed during one year [Rodolfo-Metalpa et al. 2008]. The dissociation of polyps from the coenosarc at low $\mathrm{pH}$ appears to be an essential mechanism mediated by apoptosis by which the species withstands acidification [Kvitt et al. 2015]. Although addressing the mechanisms of tissue loss was outside the scope of this study, we did not observe any evidence of tissue necrosis that might have indicated that apoptosis was involved. As observed in other zooxanthellate coral species, the symptoms of the responses to different types of stress can be similar [e.g., Gates et al. 1992; Roth et al. 2012].

Lesion recovery is fundamental to coral survival, and during this 4-yr study, the $O$. patagonica colonies began to recover shortly (a few days) after the peak of partial mortality in April and were nearly fully recovered (down to 4-8\%) from the yearly, recurrent partial mortality episodes. Over the $\sim 4$-yr study, the average regeneration rate was $10.3 \mathrm{~mm}^{2} \mathrm{~d}^{-1}$, a rate that occurred in the absence of competition with other organisms [Fine and Loya 2003]. This rate was 2.5-fold faster than the recovery rate of unbleached colonies documented in the Levant Sea [4.09 $\mathrm{mm}^{2} \mathrm{~d}^{-1}$; Fine et al. 2002]. Fine et al. [2002] observed that lesion regeneration in unbleached $O$. patagonica colonies resulted in intra-colonial translocation of resources toward recuperating lesions $4-5 \mathrm{~cm}$ away, whereas bleached colonies exhibited no lesion regeneration. These observations are consistent with tissue regeneration as an 
energetically costly process, as has been documented in other species [Oren et al. 2001]. Thus, the more rapid regeneration rate at L'Ampolla might be attributable to the timing of the recovery of the lesions during the favorable growing season, whereas in the Levant Sea, recovery was examined during the unfavorable bleaching season [Fine et al. 2001, 2002]. The denuded partial mortality of $O$. patagonica, which usually left polyps alive but isolated within the calyx, represents a characteristic pattern that may favor regeneration because (1) it increases the relationship between the wound perimeter and lesion size, which has been shown to positively correlate with the regeneration rate [Meesters et al. 1997], and (2) it rids the colony of energetically costly processes, such as calcification, and tissues [Kvitt et al. 2015]. Moreover, the small polyp size and encrusting morphology of O. patagonica colonies may help to maintain mass transfer, which also favors lesion regeneration [e.g., van Woesik et al. 2012]. The immediate initiation of regeneration at the end of the partial mortality event points to the prioritization of this life-preserving process that helps to reduce the detrimental effects of the settlement of algae and other organisms on the skeleton and the disruption of the physiological integration of the colony [Oren et al. 2001].

\section{Potential causes of the observed pattern of partial mortality and growth}

The complex interaction between ST and light on zooxanthellate corals [Lesser 1996] suggests that both factors are relevant to the seasonal dynamics of colony partial mortality in O. patagonica. However, although the loss of tissue in the coenosarc but not in the polyps might suggest a light effect, two sources of evidence suggest a secondary role of light in the observed pattern of partial mortality. First, the process of partial mortality started in December, the period with the lowest PAR levels. Second, the annual pattern of partial mortality exhibited a negative relationship with ST but not PAR.

The linear extension of $O$. patagonica colonies was positively related to ST but not to PAR, which also indicates that light might play a secondary role in the growth pattern of $O$. patagonica, in accordance with the results of previous studies [Shenkar et al. 2005; Rodolfo-Metalpa et al. 2008; Rubio-Portillo et al. 2014b]. This finding is also consistent with the lack of a negative effect of turbidity on colony growth observed by Rubio-Portillo 
et al. (2014b), who observed that growth of the colonies did not differ between a harbor and a marine protected area, despite the much greater sedimentation in the harbor and the consequent reduction in light due to turbidity. This observation supports the hypothesis that O. patagonica may have a high capacity for photoacclimation to distinct and variable light regimes that may allow it to function as a facultative zooxanthellate and thrive in a wide range of light conditions, as has been observed [Fine et al. 2001; Rodolfo-Metalpa et al. 2014]. Such characteristics would be consistent with the secondary role that light usually plays in promoting coral growth at high latitudes [Miller 1998; Rodolfo-Metalpa et al. 2008; Dimond et al. 2013]. The absence of bleaching and/or mortality in the study area in summer might be related to the relatively low PAR levels caused by river runoff, which has also been suggested to contribute to the lack of partial mortality in response to warming in the laboratory [Rodolfo-Metalpa et al. 2014].

During the four annual cycles that were examined, the partial mortality episodes at L'Ampolla occurred during the cold periods, and thus we estimated the extent of exposure of this coral species to low ST based on data from this study and previous field studies to examine whether the intensity of the partial mortality episodes was related to the severity of the cold ST period. During the warmest winter at L'Ampolla, 2008-2009 $\left(63 \mathrm{~d} \leq 13^{\circ} \mathrm{C}, 0 \mathrm{~d}\right.$ $\leq 12^{\circ} \mathrm{C}$; ESM Table S1), the peak in partial mortality (26\%) was similar to that reported during the winter of 2005-2006 in Monaco (5-20\%) under similarly cold ST conditions [66 $\mathrm{d} \leq 13^{\circ} \mathrm{C}, 0 \mathrm{~d} \leq 12^{\circ} \mathrm{C}$; Rodolfo-Metalpa et al. 2008]. By contrast, the higher incidence of partial mortality (48-66\%) during the more severe cold ST periods (2009-2010 to 20112012) at L'Ampolla could be related to exposure to the $\leq 12^{\circ} \mathrm{C}$ threshold (15-29 d; ESM Table S1), suggesting that years with severely cold ST periods increased partial mortality in O. patagonica. The analysis of published data is consistent with this hypothesis because coral populations in the mid-Balearic Sea did not suffer from partial mortality and/or visually apparent bleaching during the winter of 2010-2011 [0 d $\leq 13^{\circ} \mathrm{C}$; Rubio-Portillo et al. 2014b] nor during the examined winters since 1993 in the Levant Sea $\left[0 \mathrm{~d} \leq 16^{\circ} \mathrm{C}\right.$; e.g., Fine et al. 2001; Shenkar et al. 2005, 2006]. Thus, the degree of exposure to cold ST appears to be related to the occurrence and severity of partial mortality events. However, although the cold thermal regimes at L'Ampolla were similar between 2010 and 2012, our 
results showed that the yearly peak in O. patagonica partial mortality gradually increased during this time period (Fig. 4a; ESM Table S1). As observed during consecutive extreme summers in Porites astreoides [Schoepf et al. 2015], we hypothesize that the cumulative impact of consecutive winter events of partial mortality may have affected the physiological status (energy budget) of the colonies, thus diminishing their recovery capacity.

The recurrent and severe partial mortality of the colonies in winter indicates that cold ST may be exerting both a direct effect on the linear extension dynamics of the species and an indirect effect via partial mortality, as the growth of the colonies did not resume until the colonies recovered from their lesions. Such direct and indirect effects are consistent with (1) the lower incidence of partial mortality during the warmest first winter period at L'Ampolla (2008-2009), which reduced the time needed for complete tissue regeneration, and (2) the twofold higher linear extension detected in 2009 compared to 2010 and 2011. Our interpretation is that the high linear extension observed in summer 2009 was not an isolated estimate that could be considered an outlier because compared to the other years, linear extension in that year was also higher in spring and fall. Although the colonies in 2009 were exposed to $27^{\circ} \mathrm{C}$ during summer, the linear extension in fall suggested no detrimental effect on the colonies (probably due to the low PAR levels, see above). The lack of a detrimental effect may be related to the lower impact of partial mortality in winter 2008-2009, which permitted rapid recovery and an earlier onset of the linear extension period (Figs. 4, 5). These results suggest the occurrence of two linear extension patterns depending on the severity of the annual event of denuded partial mortality: the pattern observed in 2009, i.e., an increase with ST up to $\sim 26^{\circ} \mathrm{C}$, and that observed in the other years, i.e., an increase with ST up to $\sim 20^{\circ} \mathrm{C}$ and then a plateau, which may be related to the cost of the regeneration process (Fig. 6b). Thus, cold STs may be playing an important role in constraining the growth dynamics of $O$. patagonica at the northern limit of its distribution, in contrast to the dynamics documented in the Levant Sea, where growth occurs during the cold period (16$26^{\circ} \mathrm{C}$, November-May) and bleaching recurrently affects the colonies in summer [ $>26$ $32^{\circ} \mathrm{C}$, June-October; Fine et al. 2002; Shenkar et al. 2005]. The O. patagonica linear extension rate at L'Ampolla during the study period $\left(1.27 \mathrm{~cm}\right.$ in diameter $\left.\mathrm{yr}^{-1}\right)$ was 69 $112 \%$ higher than those in natural populations from the Levant Sea $[0.60-0.75 \mathrm{~cm}$ in 
diameter $\mathrm{yr}^{-1}$; Fine et al. 2001], suggesting that the negative effects of high ST stress occurring at the Levant Sea are more harmful than the cold ST stress occurring at the north Balearic Sea. This conclusion is consistent with previous studies documenting the effect of cold STs on corals [Gates et al. 1992; Saxby et al. 2003; Hoegh-Guldberg et al. 2005; Colella et al. 2012] and the differential effect of low- and high-ST stress on Acropora yongei [Roth et al. 2012]. However, the detrimental effect of competition on scleractinian corals [e.g., Fine and Loya 2003], which may diminish coral linear extension in natural populations, was excluded in our study.

Our results also indicate a trade-off between regeneration and linear extension that is consistent with the priority of energy allocation to recovery rather than to other biological processes. This trade-off is in agreement with previous studies from the Levant Sea, where bleaching and mortality events in O. patagonica during summer result in a low-energy state of the colonies that is responsible for the cessation of resource translocation and a reduction in gametogenesis and colony growth [Fine et al. 2001, 2002; Armoza-Zvuloni et al. 2011]. The recurrent mortality events at L'Ampolla peaked in April and overlapped temporally with the gametogenesis of $O$. patagonica [March-September; Fine et al. 2001], suggesting that this energy shortage might also impair species reproduction and population growth.

The results of this study have demonstrated that O. patagonica at this northern limit of its distribution can survive and grow under wide seasonal variation in ST (monthly mean ranging from 11.7 to $27.1^{\circ} \mathrm{C}$ ). The coral exhibits a strong seasonal cycle that includes partial mortality and cessation of linear extension during winter (December to April), tissue regeneration starting in late spring (May) and linear extension during summer and fall (June to November), a cycle that appears to be primarily driven by ST. However, our data provide only correlational evidence, and causation of the observed pattern of denuded skeleton cannot be determined without additional experimental work. Partial mortality affected approximately half of the surface area and most of the colonies $(\sim 70 \%)$ and occurred repeatedly in all four years studied, indicating that partial mortality is a crucial process affecting the dynamics of the species, the relevance of which is comparable to that of the recurrence of summer bleaching in the Levant Sea [e.g., Fine et al. 2001]. 
Due to concerns regarding the threat of global warming to tropical coral reefs, understanding the resilience of zooxanthellate corals at high latitudes is crucial for predicting shifts in coral communities and their responses to climate change. The results of our experimental exclusion from competition indicate that the recurrent and severe pattern of denuded skeletons results from unfavorable environmental conditions that may constrain the population dynamics of the coral and affect the poleward expansion of the species. However, O. patagonica can withstand harsh environments because of its high regeneration capacity, which is among the highest reported for a coral species, particularly at high latitudes [Henry and Hart 2005]. The stress response of polyp dissociation from the coenosarc appears to be a crucial pattern favoring the rapid regeneration of the species. The combination of the dissociation stress response and the rapid regeneration of the species appears to be a decisive biological characteristic that enables the species to withstand unfavorable environmental conditions affecting zooxanthellate coral species at high latitudes.

\section{Acknowledgments}

We are grateful to Marc Terrades for his assistance in the field, the Spanish State Meteorological Agency and the Catalan Water Agency for providing the solar radiation and light attenuation data, respectively; and the Parc Natural del Montgrí, les Illes Medes i el Baix Ter and the Parc Natural de Cap de Creus for their continuous support of our research. Financial support was provided by the CSI-Coral project (CGL2013-43106-R) of the Spanish Government. The authors are part of the Marine Biogeochemistry and Global Change research group of the Generalitat de Catalunya (2014SGR1029). 


\section{References}

Ainsworth TD, Fine M, Roff G, Hoegh-Guldberg O (2008) Bacteria are not the primary cause of bleaching in the Mediterranean coral Oculina patagonica. ISME J 2:67-73

Armoza-Zvuloni R, Segal R, Kramarsky-Winter E, Loya Y (2011) Repeated bleaching events may result in high tolerance and notable gametogenesis in stony corals: Oculina patagonica as a model. Mar Ecol Prog Ser 426:149-159

Colella MA, Ruzicka RR, Kidney JA, Morrison JM, Brinkhuis VB (2012) Cold-water event of January 2010 results in catastrophic benthic mortality on patch reefs in the Florida Keys. Coral Reefs 31:621-632

Coma R, Serrano E, Linares C, Ribes M, Díaz D, Ballesteros E (2011) Sea urchins predation facilitates coral invasion in a marine reserve. PLoS One 6:e22017

Dimond JL, Kerwin AH, Rotjan R, Sharp K, Stewart FJ, Thornhill DJ (2013) A simple temperaturebased model predicts the upper latitudinal limit of the temperate coral Astrangia poculata. Coral Reefs 32:401-409

Fine M, Loya Y (2003) Alternate coral-bryozoan competitive superiority during coral bleaching. Mar Biol 142:989-996

Fine M, Zibrowius H, Loya Y (2001) Oculina patagonica: a nonlessepsian scleractinian coral invading the Mediterranean Sea. Mar Biol 138:1195-1203

Fine M, Oren U, Loya Y (2002) Bleaching effect on regeneration and resource translocation in the coral Oculina patagonica. Mar Ecol Prog Ser 234:119-125

Freeman LA (2015) Robust performance of marginal Pacific coral reef habitats in future climate scenarios. PLoS One 10:e0128875

Frieler K, Meinshausen M, Golly A, Mengel M, Lebek K, Donner SD, Hoegh-Guldberg O (2013) Limiting global warming to $2^{\circ} \mathrm{C}$ is unlikely to save most coral reefs. Nat Clim Chang 3:165-170

Gates RD, Baghdasarian G, Muscatine L (1992) Temperature stress causes host cell detachment in symbiotic cnidarians: implications for coral bleaching. Biol Bull 182:324-332

Henry LA, Hart M (2005) Regeneration from injury and resource allocation in sponges and corals-a review. Int Rev Hydrobiol 90:125-158

Hoegh-Guldberg O (1999) Climate change, coral bleaching and the future of the world's coral reefs. Mar Freshw Res 50:839-866

Hoegh-Guldberg O (2012) The adaptation of coral reefs to climate change: is the Red Queen being outpaced? Sci Mar 76:403-408

Hoegh-Guldberg O, Bruno JF (2010) The impact of climate change on the world's marine ecosystems. Science 328:1523-1528

Hoegh-Guldberg O, Fine M, Skirving W, Johnstone R, Dove S, Strong A (2005) Coral bleaching following wintry weather. Limnol Oceanogr 50:265-271 
Hughes TP, Graham NAJ, Jackson JBC, Mumby PJ, Steneck RS (2010) Rising to the challenge of sustaining coral reef resilience. Trends Ecol Evol 25:633-642

Kleypas JA, McManus JW, Meñez LAB (1999) Environmental limits to coral reef development: where do we draw the line? Am Zool 39:146-159

Kvitt H, Kramarsky-Winter E, Maor-Landaw K, Zandbank K, Kushmaro A, Rosenfeld H, Fine M, Tchernov D (2015) Breakdown of coral colonial form under reduced $\mathrm{pH}$ conditions is initiated in polyps and mediated through apoptosis. Proc Natl Acad Sci USA 112:2082-2086

Lesser MP (1996) Elevated temperatures and ultraviolet radiation cause oxidative stress and inhibit photosynthesis in symbiotic dinoflagellates. Limnol Oceanogr 41:271-283

Leydet KP, Hellberg ME (2015) The invasive coral Oculina patagonica has not been recently introduced to the Mediterranean from the western Atlantic. BMC Evol Biol 15:79

Meesters EH, Pauchli W, Bak RPM (1997) Predicting regeneration of physical damage on a reefbuilding coral by regeneration capacity and lesion shape. Mar Ecol Prog Ser 146:91-99

Miller MW (1998) Coral/seaweed competition and the control of reef community structure within and between latitudes. Oceanogr Mar Biol Annu Rev 36:65-96

Muir PR, Wallace CC, Done T, Aguirre JD (2015) Limited scope for latitudinal extension of reef corals. Science 348:1135-1138

Oren U, Benayahu Y, Lubinevsky H, Loya Y (2001) Colony integration during regeneration in the stony coral Favia favus. Ecology 82:802-813

Pandolfi JM, Connolly SR, Marshall DJ, Cohen AL (2011) Projecting coral reef futures under global warming and ocean acidification. Science 333:418-422

Pratchett MS, Anderson KD, Hoogenboom MO, Widman E, Baird AH, Pandolfi JM, Edmunds PJ, Lough JM (2015) Spatial, temporal and taxonomic variation in coral growth-implications for the structure and function of coral reef ecosystems. Oceanogr Mar Biol Annu Rev 53:215-295

Rodolfo-Metalpa R, Reynaud S, Allemand D, Ferrier-Pagès C (2008) Temporal and depth responses of two temperate corals, Cladocora caespitosa and Oculina patagonica, from the north Mediterranean Sea. Mar Ecol Prog Ser 369:103-114

Rodolfo-Metalpa R, Hoogenboom MO, Rottier C, Ramos-Esplá A, Baker AC, Fine M, Ferrier-Page`s C (2014) Thermally tolerant corals have limited capacity to acclimatize to future warming. Glob Chang Biol 20:3036-3049

Roth MS, Goericke R, Deheyn DD (2012) Cold induces acute stress but heat is ultimately more deleterious for the reef-building coral Acropora yongei. Sci Rep 2:240

Rubio-Portillo E, Vázquez-Luis M, Izquierdo-Muñoz A, Ramos-Esplá AA (2014a) Distribution patterns of alien coral Oculina patagonica De Angelis D’Ossat, 1908 in western Mediterranean Sea. J Sea Res 85:372-378 
Rubio-Portillo E, Vázquez-Luis M, Valle C, Izquierdo-Muñoz A, Ramos-Esplá AA (2014b) Growth and bleaching of the coral Oculina patagonica under different environmental conditions in the western Mediterranean Sea. Mar Biol 161:2333-2343

Salomidi M, Katsanevakis S, Issaris Y, Tsiamis K, Katsiaras N (2013) Anthropogenic disturbance of coastal habitats promotes the spread of the introduced scleractinian coral Oculina patagonica in the Mediterranean Sea. Biol Invasions 15:1961-1971

Saxby T, Dennison WC, Hoegh-Guldberg O (2003) Photosynthetic responses of the coral Montipora digitata to cold temperature stress. Mar Ecol Prog Ser 248:85-97

Schoepf V, Grottoli AG, Levas SJ, Aschaffenburg MD, Baumann JH, Matsui Y, Warner ME (2015) Annual coral bleaching and the long-term recovery capacity of coral. Proc R Soc Lond B Biol Sci 282:20151887

Serrano E, Coma R, Ribes M (2012) A phase shift from macroalgal to coral dominance in the Mediterranean. Coral Reefs 31:1199

Serrano E, Coma R, Ribes M, Weitzmann B, García M, Ballesteros E (2013) Rapid northward spread of a zooxanthellate coral enhanced by artificial structures and sea warming in the western Mediterranean. PLoS One 8:e52739

Shenkar N, Fine M, Loya Y (2005) Size matters: bleaching dynamics of the coral Oculina patagonica. Mar Ecol Prog Ser 294:181-188

Shenkar N, Fine M, Kramarsky-Winter E, Loya Y (2006) Population dynamics of zooxanthellae during a bacterial bleaching event. Coral Reefs 25:223-227

Takao S, Yamano H, Sugihara K, Kumagai NH, Fujii M, Yamanaka Y (2015) An improved estimation of the poleward expansion of coral habitats based on the inter-annual variation of sea surface temperatures. Coral Reefs 34:1125-1137

van Woesik R, Irikawa A, Anzai R, Nakamura T (2012) Effects of coral colony morphologies on mass transfer and susceptibility to thermal stress. Coral Reefs 31:633-639 
Figures and Tables (Main text \& Supplementary)

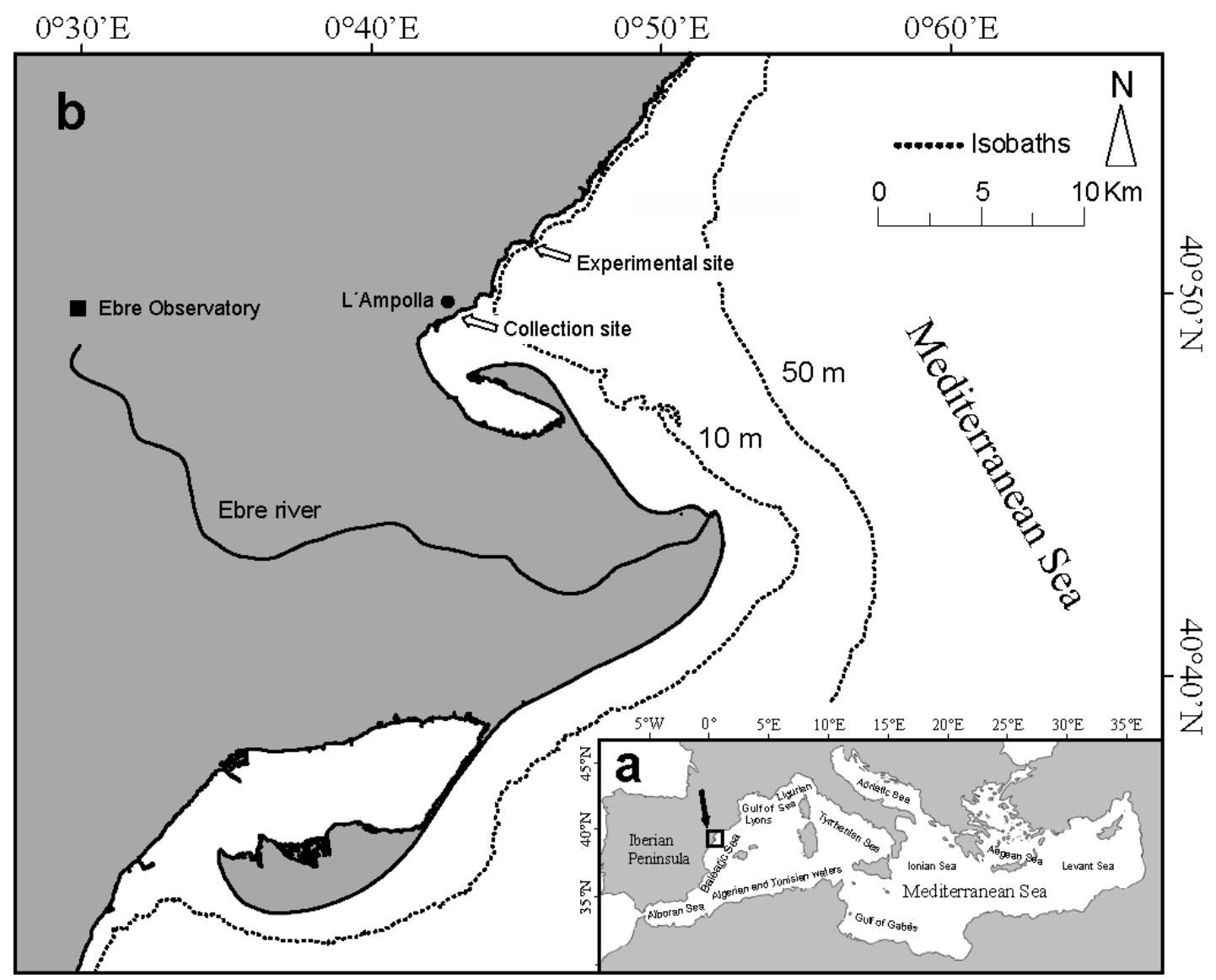

Fig. 1 a Map of the Mediterranean Sea showing the study area (L'Ampolla) in the north Balearic Sea. b Location of the collection site and the experimental site 
Partial mortality events of O. patagonica in winter |
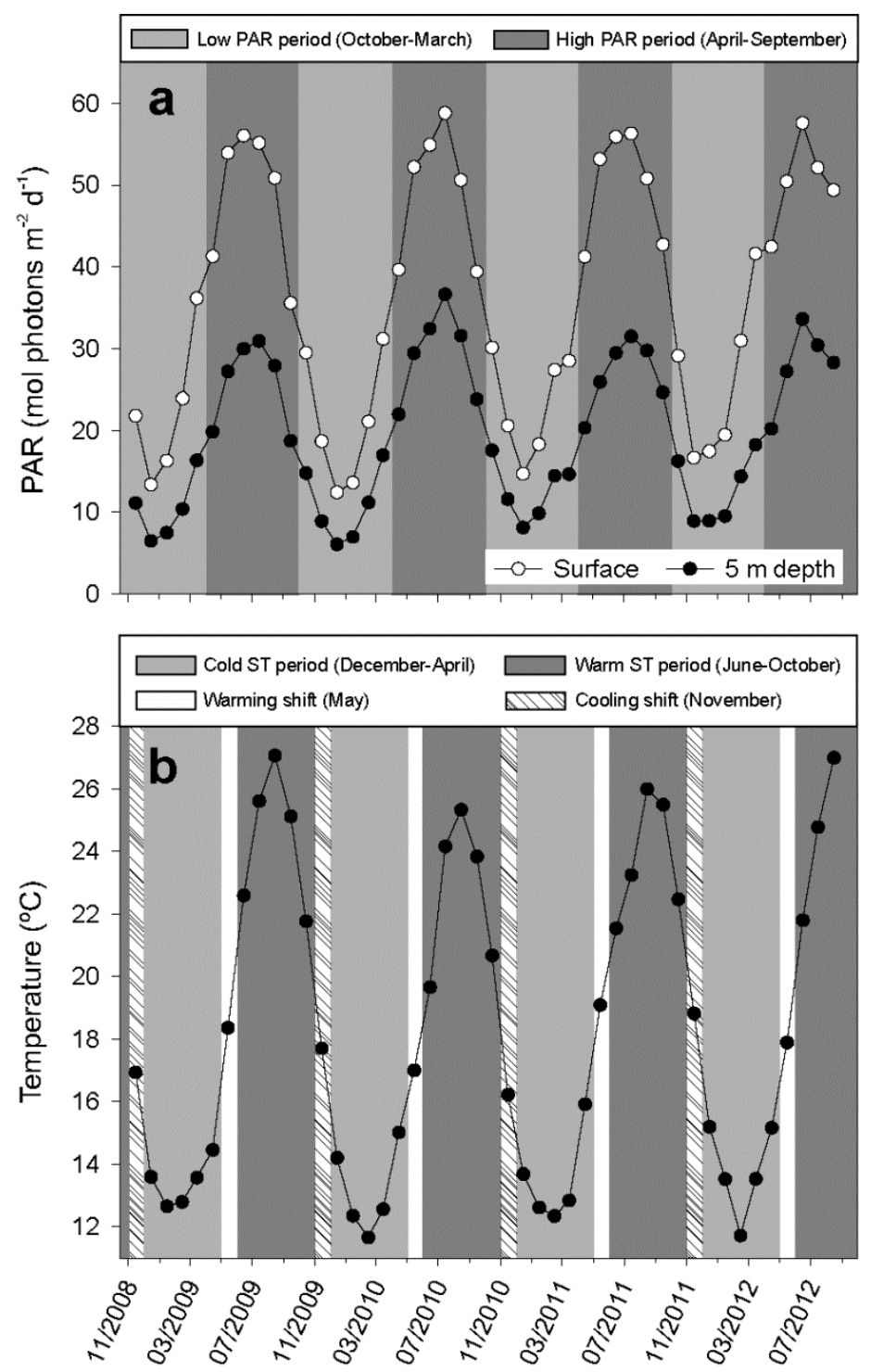

Fig. 2 a Monthly mean photosynthetically active radiation (PAR) at sea surface and $5 \mathrm{~m}$ depth at L'Ampolla. b Monthly mean seawater temperature (ST) at $5 \mathrm{~m}$ depth at L'Ampolla 


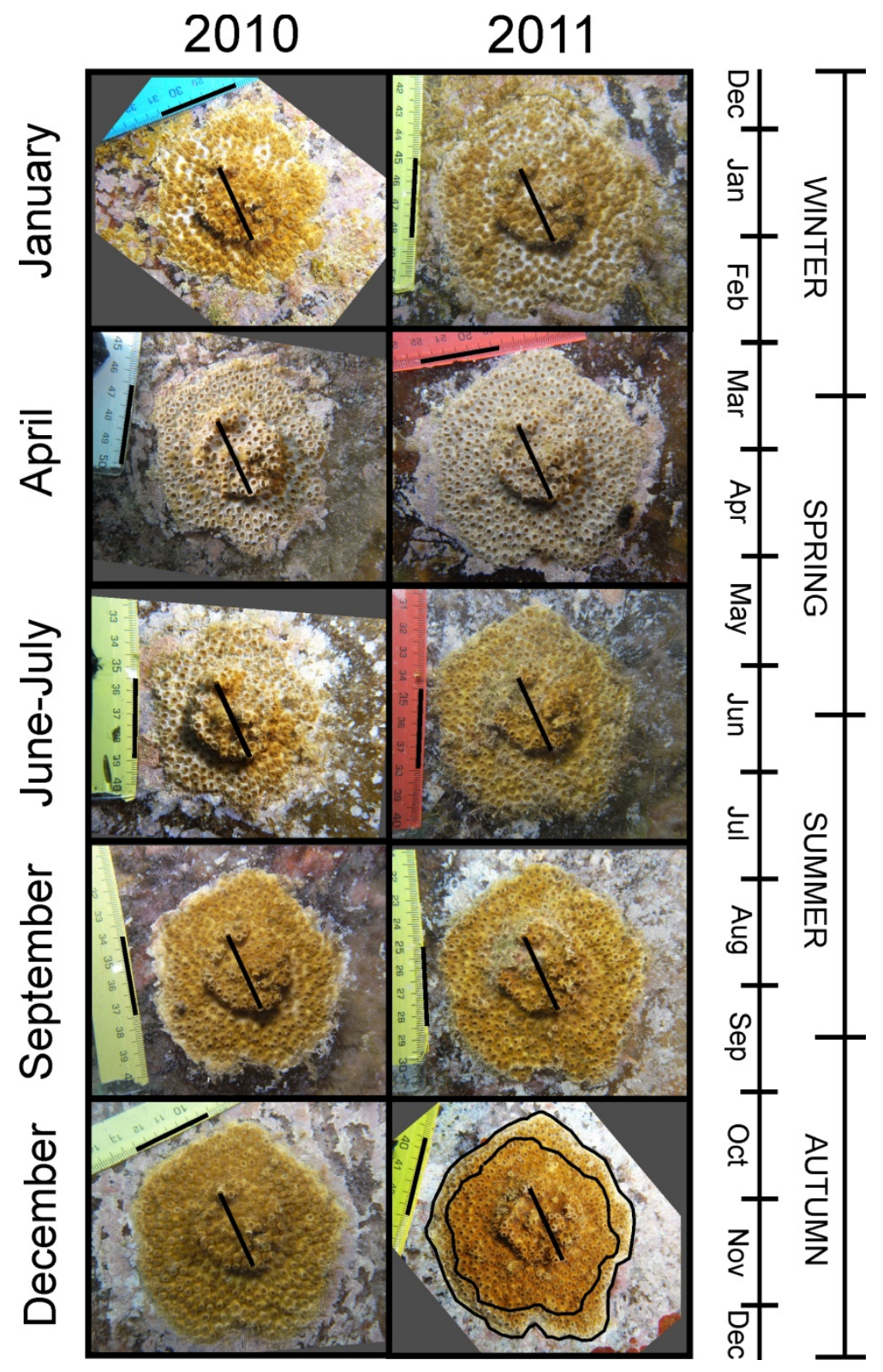

Fig. 3 Monitoring of a colony of Oculina patagonica from January 2010 to December 2011. Partial mortality occurred during winter and early spring, followed by recovery in late spring and linear extension during summer and autumn. The perimeter from January 2010 is superimposed on that from December 2011. Scale bars $3.40 \mathrm{~cm}$ 
Partial mortality events of O. patagonica in winter |
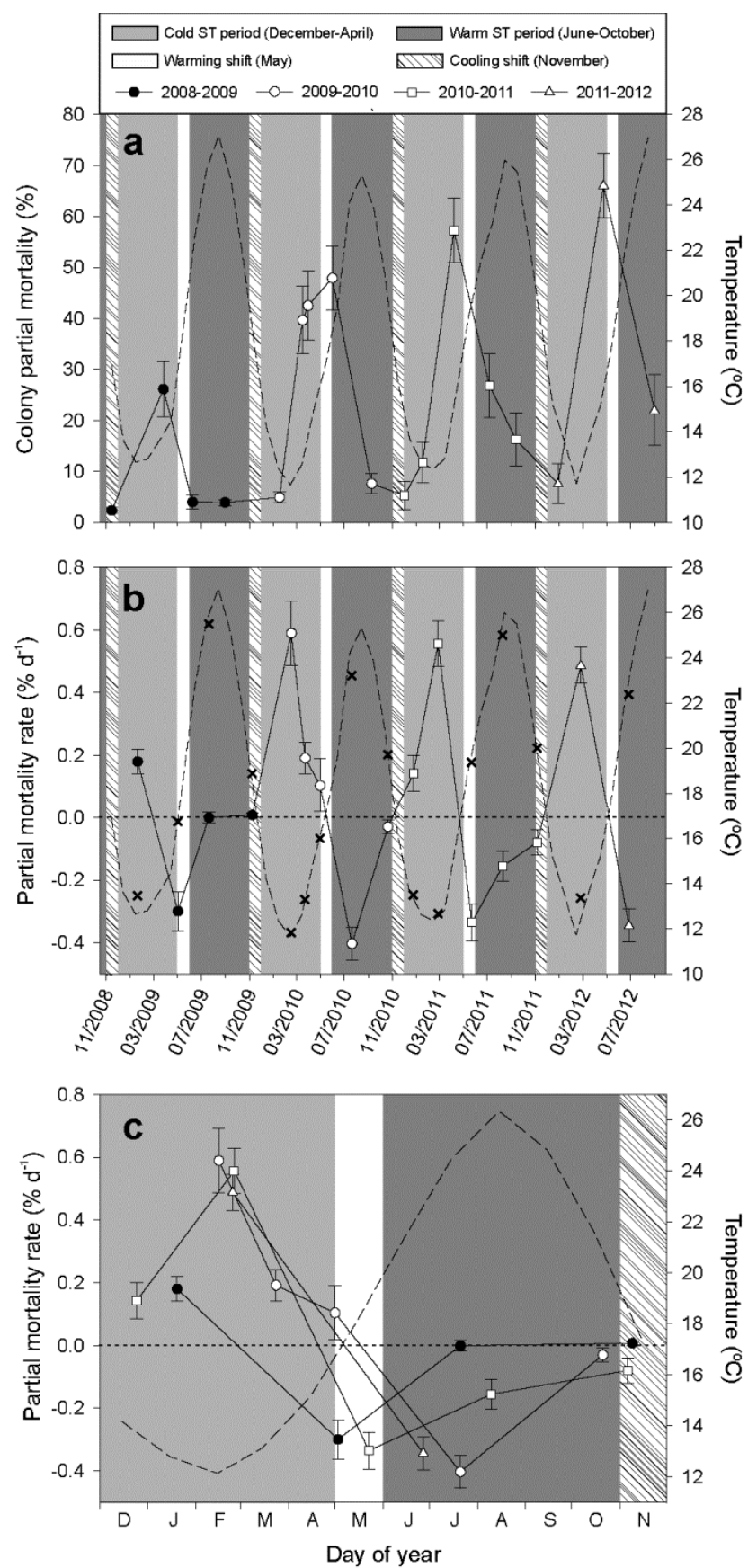

Fig. 4 Partial mortality of Oculina patagonica and seawater temperature (ST, dashed lines and crosses) at L'Ampolla. a Proportion of colony partial mortality on each sampling date $(n=17)$. Colony partial mortality rate $\mathbf{b}$ over the study period and $\mathbf{c}$ on an ordinal date for each sampling interval $(n=16)$. Values are mean \pm SE 
Partial mortality events of O. patagonica in winter |
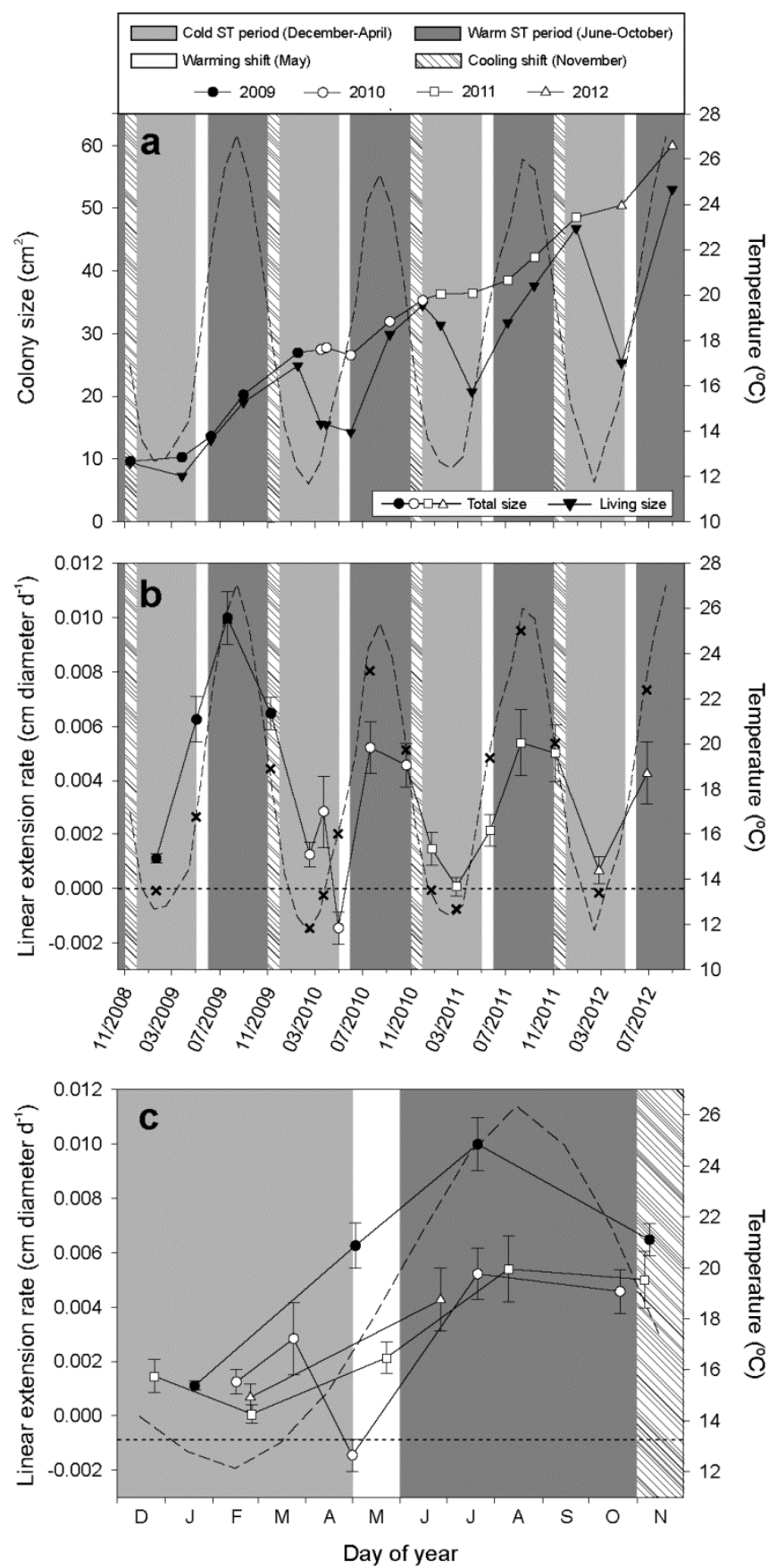

Fig. 5 Linear extension of Oculina patagonica and seawater temperature (ST, dashed lines and crosses) at L'Ampolla. a Total and living colony size on each sampling date $(n=17)$. Colony linear extension rate $\mathbf{b}$ over the study period and $\mathbf{c}$ on an ordinal date for each sampling interval $(n=16)$. Values are mean $\pm \mathrm{SE}$ 

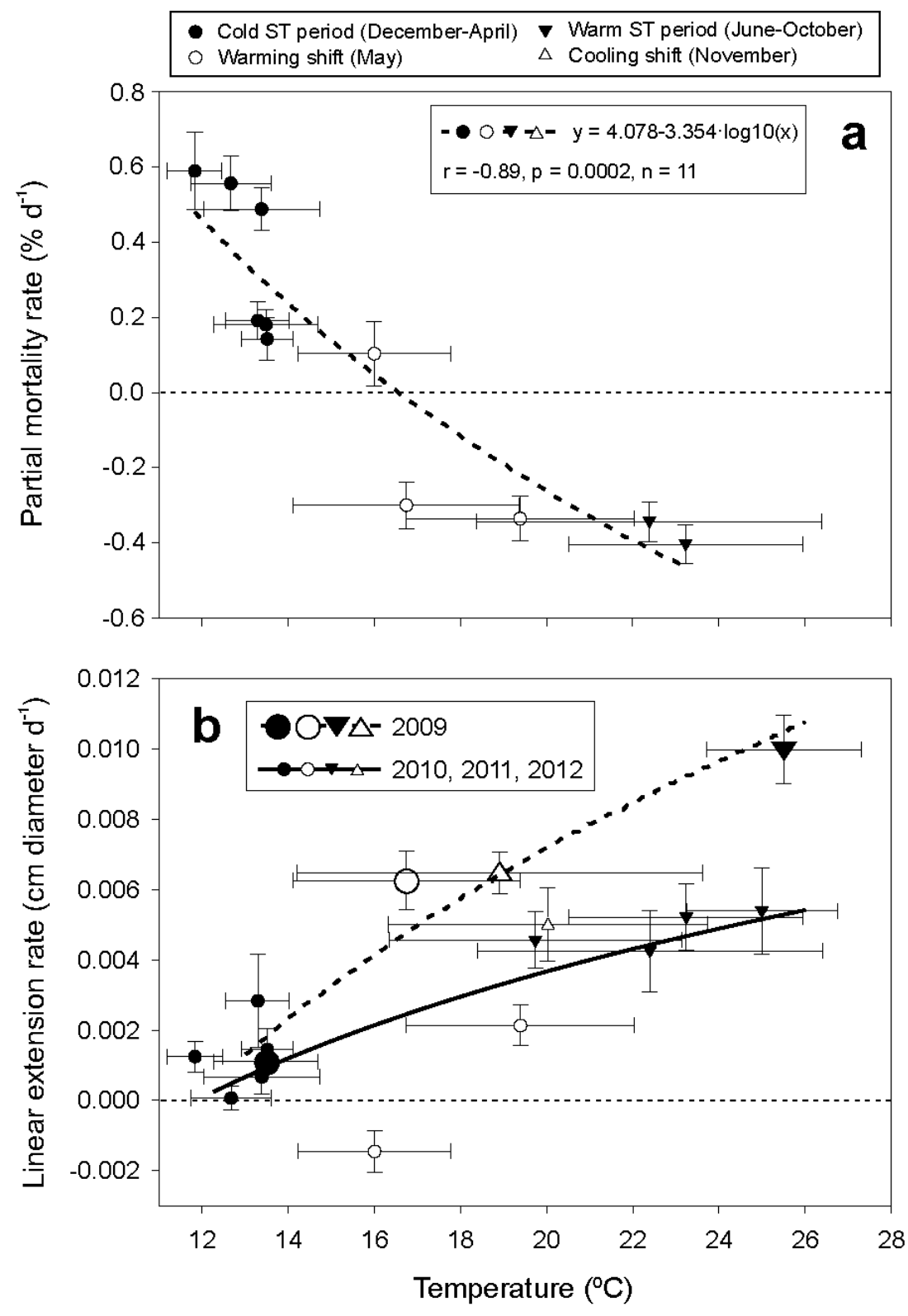

Fig. 6 Pearson product-moment correlations between Oculina patagonica performance and seawater temperature (ST) for each sampling interval. a Colony partial mortality rate. Values from the late warm ST and cooling shift periods were not included because lesion regeneration was already completed or was strongly affected by algal overgrowth. b Colony linear extension rate. Values are mean $\pm \mathrm{SE}$ for coral performance and mean $\pm \mathrm{SD}$ for ST. Two linear extension patterns depending on the severity of the annual event of denuded partial mortality are depicted: the pattern observed in 2009 (dashed line) and that observed in 2010, 2011 and 2012 (solid line). Data were fitted to logarithmic functions 


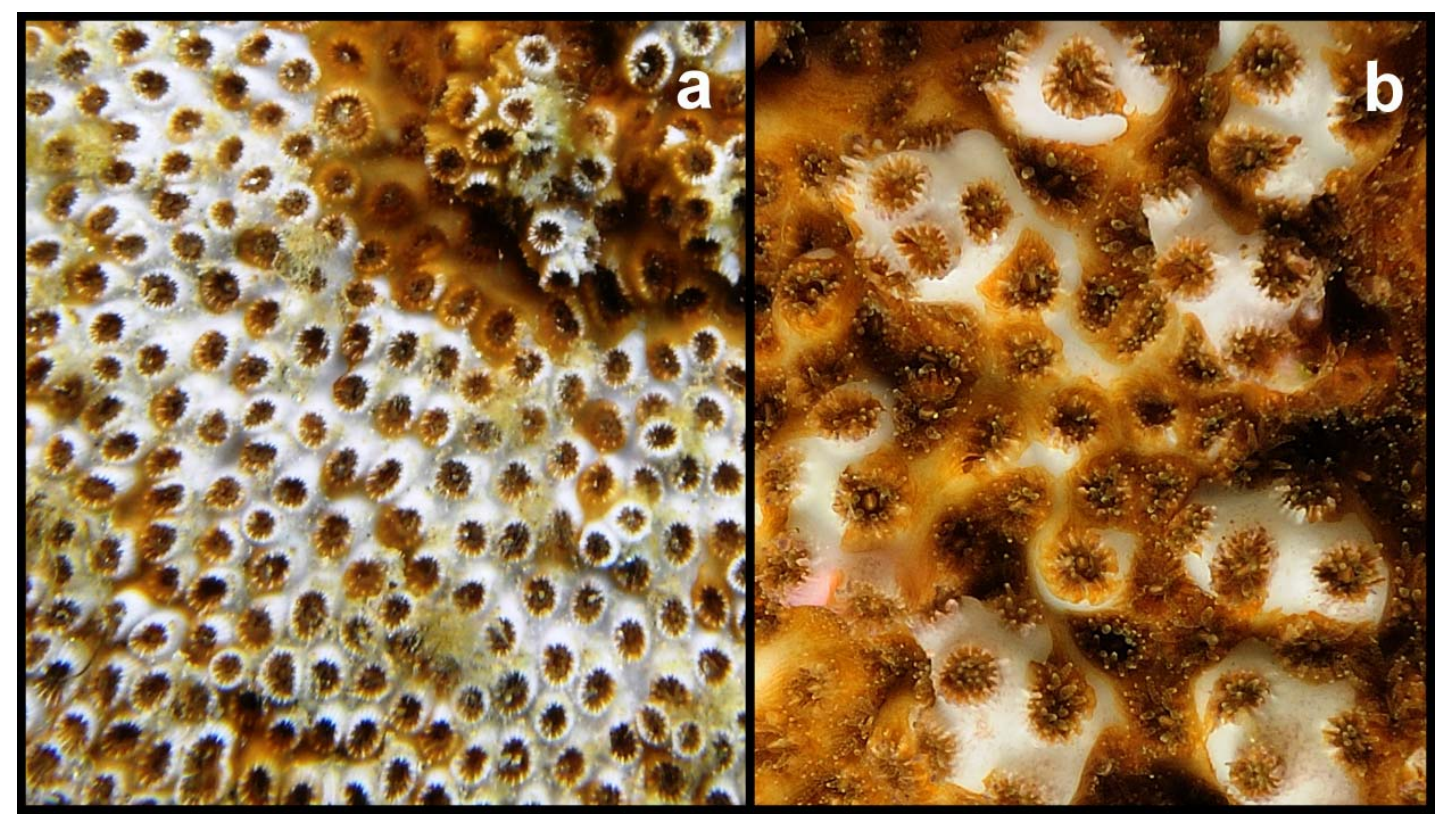

Fig. 7 Dalmatian mortality pattern in Oculina patagonica: a general view and b close-up view 

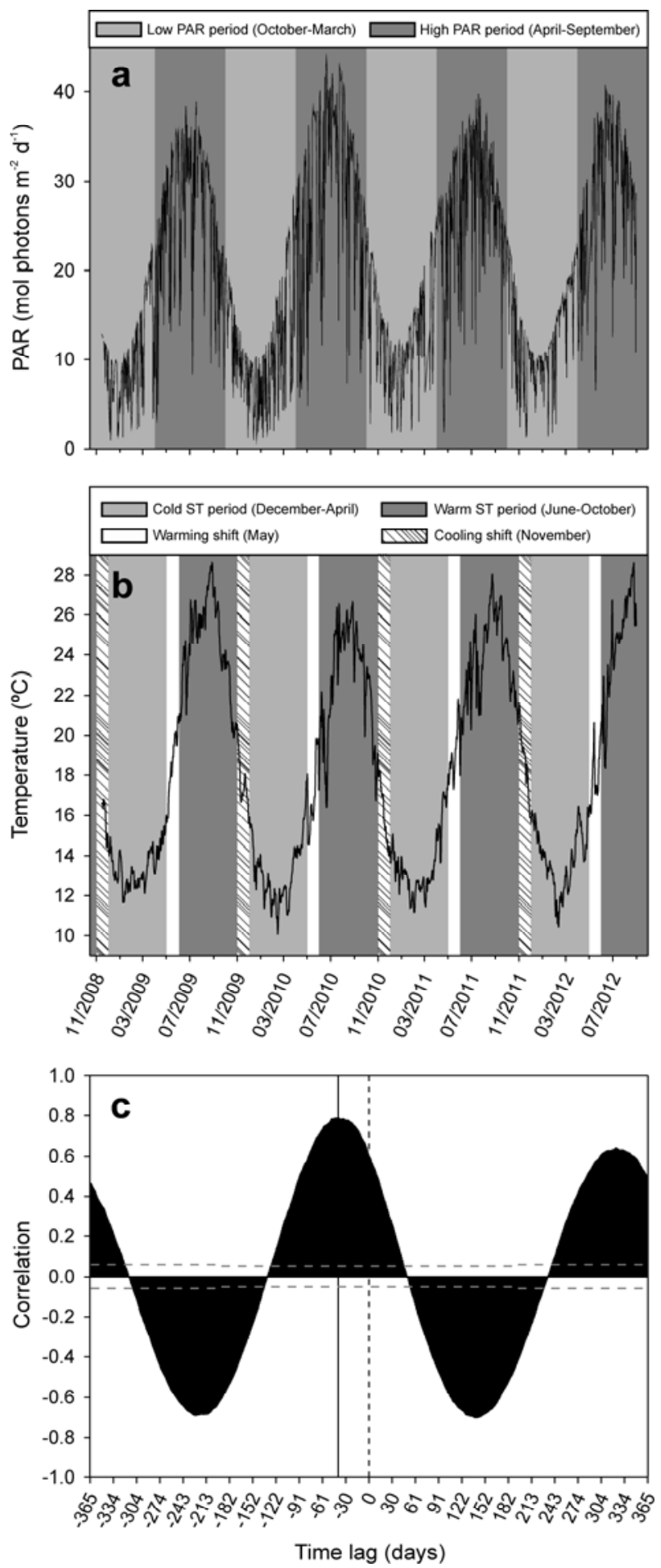

Fig. S1 Environmental parameters measured during the study period (November 2008August 2012) at 5-m depth at L'Ampolla. (a) Daily mean photosynthetically active radiation (PAR). (b) Daily mean seawater temperature (ST). (c) Cross-correlation analysis between $\mathrm{PAR}$ and ST. The solid vertical line indicates the maximum significance at a lag of $-40 \mathrm{~d}(\mathrm{r}=$ 0.79), whereas the dashed vertical line indicates the correlation coefficient at a lag of $0 \mathrm{~d}(\mathrm{r}=$ $0.60)$. Bars that reach or pass the dashed horizontal lines have significant $(\mathrm{p}<0.05)$ positive (upper) or negative (lower) correlation values 


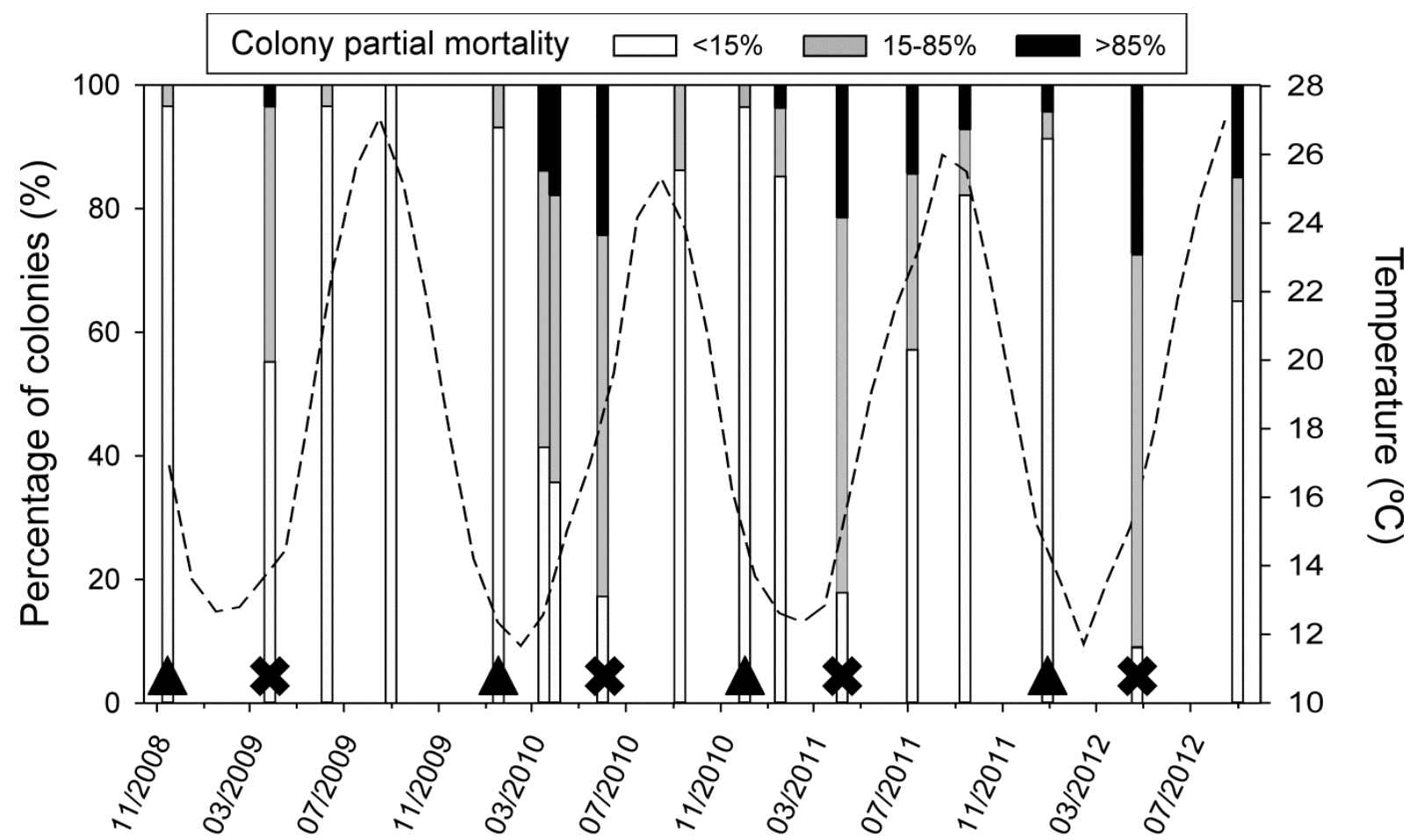

Fig. S2 Proportion of colony partial mortality in the coral Oculina patagonica classified into three levels of severity: mild (<15\%), moderate $(>15-85 \%)$ or severe $(>85 \%)$ throughout the study period (November 2008-August 2012, n = 17 sampling dates) at L'Ampolla. Mean monthly seawater temperature data (dashed line) are superimposed. Sampling dates with minimum (black triangles) and maximum (black crosses) incidence of partial mortality are highlighted for each annual cycle 

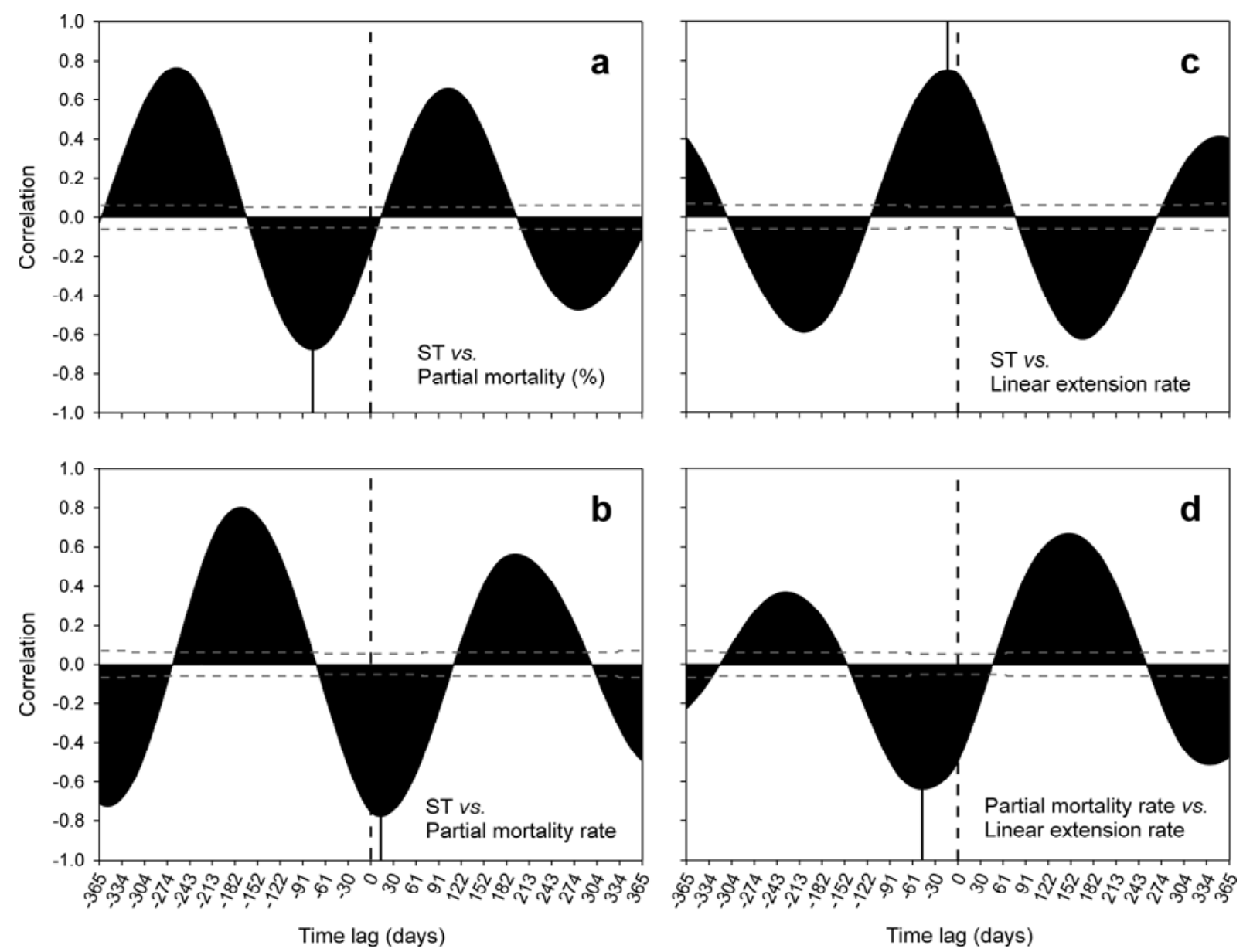

Fig. S3 Cross-correlation analyses between coral performance and seawater temperature (ST) throughout the study period (November 2008-August 2012) at L'Ampolla. (a) ST and proportion of colony partial mortality (\%). The solid vertical line indicates the maximum significance at a lag of $-78 \mathrm{~d}(\mathrm{r}=-0.68)$; the dashed vertical line indicates the correlation coefficient at a lag of $0 \mathrm{~d}(\mathrm{r}=-0.16)$. (b) ST and colony partial mortality rate $\left(\% \mathrm{~d}^{-1}\right)$. The solid vertical line indicates the maximum significance at a lag of $+13 d(r=-0.78)$, which does not differ from the dashed vertical line indicating the correlation coefficient at a lag of 0 $\mathrm{d}(\mathrm{r}=-0.76)$. (c) ST and colony linear extension rate $\left(\mathrm{cm}\right.$ diameter $\left.\mathrm{d}^{-1}\right)$. The solid vertical line indicates the maximum significance at a lag of $-13 d(r=0.75)$, which does not differ from the dashed vertical line indicating the correlation coefficient at a lag of $0 \mathrm{~d}(\mathrm{r}=0.73)$. (d) Colony partial mortality rate $\left(\% \mathrm{~d}^{-1}\right)$ and colony linear extension rate $\left(\mathrm{cm}\right.$ diameter $\left.\mathrm{d}^{-1}\right)$. The solid vertical line indicates the maximum significance at a lag of $-48 \mathrm{~d}(\mathrm{r}=-0.64)$; the dashed vertical line indicates the correlation coefficient at a lag of $0 \mathrm{~d}(\mathrm{r}=-0.50)$. Bars that reach or pass the dashed horizontal lines have significant $(\mathrm{p}<0.05)$ positive (upper) or negative (lower) correlation values 


\section{Supplementary methods}

The integrated daily irradiance $\left(\mathrm{J} \mathrm{m}^{-2} \mathrm{~d}^{-1}\right)$ throughout the study period was determined based on the cumulated hourly values averaged for each daily cycle (Ebre Observatory, Spanish State Meteorological Agency). The daily photosynthetically active radiation (PAR, mol photons $\mathrm{m}^{-2} \mathrm{~d}^{-1}$ ) was obtained from global irradiance using a conversion coefficient of $4.57 \times 10^{-6} \mathrm{~mol} \mathrm{~J}^{-1}$ (Thimijan and Heins 1983) and a ratio of PAR to total radiation of 0.50 (Monteith 1970). Light attenuation coefficient data were regularly recorded by the Catalan Water Agency at both the collection and the experimental sites within the study area and were employed to calculate the PAR at $5 \mathrm{~m}$ depth. Mean annual and monthly PAR were determined based on the daily values averaged over the study period.

The study area is a homogeneous shallow-water coast influenced by the Ebre river runoff. The comparison of the seawater temperature from data loggers (Onset HOBO UA-002-64) between the collection and the experimental sites revealed no differences (Pearson product-moment correlation, $\mathrm{r}^{2}$ $=0.99, \mathrm{p}<0.0001)$. There was also no difference in the light attenuation coefficient values between sites (Chi-square, $\chi^{2}=11.99, \mathrm{p}=0.52$ ).

\section{References}

Monteith JL (1970) Light interception and radiative exchange in crop stands. In: Eastin JD (ed) Physiological aspects of crop yield. ASA, Madison, Wisconsin, pp 89-109

Thimijan RW, Heins RD (1983) Photometric, radiometric, and quantum light units of measure: a review of procedures for interconversion. HortScience 18:818-822 
Table S1 Seawater temperature (ST) thresholds obtained from temperature sensors placed in situ at a depth of $5 \mathrm{~m}$ at L'Ampolla. (a) Number of days on which the ST was $\leq 19$ to $\leq 11^{\circ} \mathrm{C}$ during the cold seasons of 2008-2009 to 2011-2012 ( $\mathrm{n}=4$ ). (b) Number of days on which the ST was $\geq 20$ to $\geq 28^{\circ} \mathrm{C}$ during the warm seasons of 2009 to $2011(\mathrm{n}=3)$. The mean proportion of colony partial mortality documented on Oculina patagonica is indicated for each season.

\begin{tabular}{|c|c|c|c|c|c|c|c|c|c|c|}
\hline (a) Cold season & $\leq 19^{\circ} \mathrm{C}$ & $\leq 18^{\circ} \mathrm{C}$ & $\leq 17^{\circ} \mathrm{C}$ & $\leq 16^{\circ} \mathrm{C}$ & $\leq 15^{\circ} \mathrm{C}$ & $\leq 14^{\circ} \mathrm{C}$ & $\leq 13^{\circ} \mathrm{C}$ & $\leq 12^{\circ} \mathrm{C}$ & $\leq 11^{\circ} \mathrm{C}$ & $\begin{array}{c}\text { Partial } \\
\text { mortality } \\
(\%)\end{array}$ \\
\hline 2008-2009 & 202 & 185 & 175 & 162 & 143 & 94 & 63 & 0 & 0 & 26 \\
\hline 2009-2010 & 199 & 196 & 176 & 161 & 129 & 104 & 73 & 29 & 0 & 48 \\
\hline 2010-2011 & 207 & 175 & 165 & 151 & 135 & 108 & 63 & 15 & 0 & 57 \\
\hline 2011-2012 & 192 & 189 & 163 & 141 & 112 & 81 & 44 & 17 & 0 & 66 \\
\hline (b) Warm season & $\geq 20^{\circ} \mathrm{C}$ & $\geq 21^{\circ} \mathrm{C}$ & $\geq 22^{\circ} \mathrm{C}$ & $\geq 23^{\circ} \mathrm{C}$ & $\geq 24^{\circ} \mathrm{C}$ & $\geq 25^{\circ} \mathrm{C}$ & $\geq 26^{\circ} \mathrm{C}$ & $\geq 27^{\circ} \mathrm{C}$ & $\geq 28^{\circ} \mathrm{C}$ & $\begin{array}{c}\text { Partial } \\
\text { mortality } \\
(\%)\end{array}$ \\
\hline 2009 & 164 & 135 & 125 & 109 & 90 & 75 & 41 & 22 & 0 & 0 \\
\hline 2010 & 136 & 111 & 105 & 88 & 69 & 60 & 0 & 0 & 0 & 0 \\
\hline 2011 & 165 & 148 & 128 & 83 & 66 & 47 & 34 & 0 & 0 & 0 \\
\hline
\end{tabular}

ST thresholds are based on mean daily values. To examine whether exposure to cold ST thresholds ( $\leq 19$ to $\leq 11^{\circ} \mathrm{C}$ ) impacted the species, we determined the fall/winter days on which ST dropped below each threshold and the days in spring/early summer of the next year on which it rose above each threshold. To examine whether exposure to warm ST thresholds $\left(\geq 20\right.$ to $\left.\geq 28^{\circ} \mathrm{C}\right)$ affected the species, we determined the days in spring/summer on which the ST reached each threshold and the days in late summer/fall on which it dropped below each threshold. To avoid any bias introduced by shortterm ST oscillations, we determined that the daily mean ST values had to remain $\leq$ or $\geq$ each threshold on at least $80 \%$ of the days throughout the following two weeks (i.e., 11 of $14 \mathrm{~d}$ ) after the date on which the ST crossed the threshold to be considered 